\section{Rowcovers and Strip Tillage Provide an Alternative to Plasticulture Systems in Summer Squash Production}

\author{
Jennifer Tillman and Ajay Nair ${ }^{1}$ \\ Department of Horticulture, 106 Horticulture Hall, Iowa State University, \\ Ames, IA 50011 \\ Mark Gleason and Jean Batzer \\ Department of Plant Pathology and Microbiology, 351 Bessey Hall, Iowa \\ State University, Ames, IA 50011
}

Additional index words. black plastic mulch, cereal rye, cover crop, cucurbit, roller crimper, spunbonded

\begin{abstract}
Plastic mulch is often used in cucurbit production, but it has negative soil health and environmental implications due to use of tillage for installation and generation of plastic waste. This 2-year study aimed to find a viable alternative to plastic mulch through the use of strip tillage and rowcovers, as rowcovers could help minimize yield loss from strip tillage by providing warmer air and soil as well as providing insect protection. A split-plot design was used in both conventionally and organically managed summer squash (Cucurbita pepo), with production system as the whole-plot factor [conventional tillage with black plastic mulch also referred to as plasticulture (PL) and strip tillage into rolled cereal rye (Secale cereale) (ST)] and rowcover use as the subplot factor (rowcover until anthesis or no rowcover). Rowcovers reduced the incidence of squash vine borer (Melittia cucurbitae) and eliminated the need for insecticide sprays to control this insect pest, but did not reduce the incidence of yellow vine decline or the sprays needed to control squash bug (Anasa tristis). Rowcovers increased average air temperature by 1.6 to $4.0^{\circ} \mathrm{C}$ and increased maximum air temperature by up to $10.3{ }^{\circ} \mathrm{C}$. Rowcovers decreased average light intensity by $33 \%$ to $39 \%$. Though soil temperature in PL tended to be higher than in ST, in 1-year rowcovers helped bridge the gap. Plant biomass was consistently higher in the PL than the ST system. Averaged across rowcover treatments, plants in PL had higher marketable yields than those in ST; however, the use of rowcovers often led to comparable yields between the production system treatments. Rowcover was a significant factor explaining marketable yield for the organically managed fields both years. There was no consistent effect of production system on soil microbial biomass carbon (MBC). Based on our results, strip tillage into rolled rye could be a viable alternative to plasticulture for summer squash production in Iowa, and rowcovers could help increase yields in ST especially in an organic management system.
\end{abstract}

Plastic mulch is commonly used by commercial producers of cucurbits because it increases soil temperature, reduces weed pressure, retains soil moisture, and increases earliness of harvest (Lamont, 2005). Compared with bare ground systems, black plastic mulch can increase yields of cucumber (Ibarra-Jiménez et al., 2004), muskmelon (Ibarra et al., 2001), and summer squash (Mahadeen, 2014). However, there

\footnotetext{
Received for publication 7 May 2015. Accepted for publication 21 Oct. 2015.

This paper is part of a thesis by the first author for a M.S. degree.

This work was supported by USDA Specialty Crop Research Initiative grant no. 2012-51181-20295.

We thank Vince Lawson and Justin Rinas at the Muscatine Island Research and Demonstration Farm for their help managing the field experiments; Cynthia Cambardella and Jody Ohmacht at the National Laboratory for Agriculture and the Environment for their help analyzing soil microbial biomass carbon; and the students from Iowa State University who helped with field and laboratory work.

${ }^{1}$ Corresponding author. E-mail: nairajay@iastate.edu.
}

One way to end cover crops without tillage is to use a roller crimper, which is a tractor-mounted implement with a waterfilled rolling drum, typically 3 to $4.5 \mathrm{~m}$ wide and having $0.6 \mathrm{~m}$ diameter that mechanically ends a cover crop by crimping the stems while leaving the root system and soil undisturbed (Parr et al., 2011). The rolled and crimped residue is then left intact on the soil surface to serve as biological mulch that can be used as an alternative to plastic mulch. This technique can be adapted to a strip tillage system by minimally disturbing one narrow strip for planting, leaving the mulch between rows undisturbed. Soils covered with heavy residue may be cooler than bare soil (Schonbeck and Evanylo, 1998), and residues on the surface can prevent weeds (Leavitt et al., 2011) and sustain soil moisture (Schonbeck and Evanylo, 1998). RebergHorton et al. (2012) also reported significant weed control using cover crop mulches; however, to achieve high levels of weed control it is imperative to obtain substantial cover crop biomass. Rolled cover crop systems can lead to yields equivalent to those of tilled, bare ground systems for pumpkin (Wyenandt et al., 2011), organic bell pepper (Delate, 2008), winter squash (Hoyt, 1999), and tomato (Hoyt, 1999). However, Leavitt et al. (2011) found that tomato, zucchini, and bell pepper in a no-till rolled cover crop system in Minnesota had lower yields than in a conventionally tilled system without cover crops, potentially due to the cool northern U.S. climate. These mixed results indicate the need for a technique to mitigate the potential yield loss when using a rolled cover crop system as opposed to bare ground.

Given the increased yields in plasticulture systems compared with bare ground, little work has been done comparing conventional management using plastic to systems that reduce tillage through low-disturbance alternatives such as strip tillage, especially in warm-season crops like cucurbits. One way to overcome the possible yield loss in a rolled cover crop system is to use rowcovers. Rowcovers can increase air temperature and soil temperature (Ibarra et al., 2001) and have been shown to increase yield of muskmelon (Cline et al., 2008), cucumber (Nair and Ngouajio, 2010), and watermelon (Soltani et al., 1995). By physically preventing insects from reaching young plants, rowcovers can prevent damage from insect feeding and reduce the spread of insect-transmitted pathogens like Erwinia tracheiphila (Saalau Rojas et al., 2011). This pathogen is spread by spotted and striped cucumber beetles (Diabrotica undecimpunctata and Acalymma vittatum) and causes cucurbit bacterial wilt, a devastating disease for cucurbit growers. Another important insecttransmitted disease, yellow vine decline, is caused by Serratia marcescens, a pathogen spread by squash bugs (Bruton et al., 2003).

We had two primary objectives: 1 ) determine if using rowcovers in a strip tillage system can produce equivalent summer squash yield to a plasticulture system and 2) evaluate differences in yellow squash growth and yield with 
or without spunbonded rowcovers and microclimate modifications that come along with rowcover use. We compared two production systems [conventional tillage with black plastic mulch (PL) and strip tillage into rolled cereal rye (ST)] with and without the use of rowcovers in organically and conventionally managed fields of summer squash. We evaluated these practices in two management systems (organic and conventional) due to the increased interest in using ST system by organic vegetable growers and growing number of conventional growers who have started valuing the importance of cover crops and view it as a tool to improve soil organic matter and a transitional tool to be more sustainable in their production. Conducting this research in both production systems allows for a wider impact over a large number of cucurbit growers.

\section{Materials and Methods}

\section{Experimental site}

Trials were conducted in fruitfield coarse sand (sandy, mixed, mesic Entic Hapludolls) at the Muscatine Island Research and Demonstration Farm in Fruitland, IA (lat. 041 $21^{\prime} 15^{\prime \prime} \mathrm{N}$, long. $\left.091^{\circ} 08^{\prime} 08^{\prime \prime} \mathrm{W}\right)$. The 2013 field had previously been in sorghum sudangrass, and the 2014 field had previously been in a corn/soybean rotation under conventional management.

\section{Planting material}

For the conventionally managed field, 'Lioness' yellow summer squash seeds (Seedway, Hall, NY) treated with thiamethoxam, azoxystrobin, mefenoxam, and fludioxonil were sowed into 72-cell trays with potting mix (Metro Mix 360; Sun Gro Horticulture, Agawam, MA). Untreated 'Lioness' yellow summer squash seeds were sowed with organic potting mix (Mix no. 11; Beautiful Land Products, West Branch, IA) into 72-cell trays for the organically managed field.

\section{Experimental design and treatments}

A split-plot complete block design with four replications was used for both organically and conventionally managed fields, with a $3.7-\mathrm{m}$ buffer area between the fields. Within each management system (organic or conventional), the whole-plot factor was production system [strip tillage into rolled cereal rye (ST) or conventional tillage with black plastic mulch (PL)] and the subplot factor was rowcover use (rowcover or no rowcover). Spacing between rows was $1.8 \mathrm{~m}$. A guard row separated whole-plot treatments. Each subplot experimental unit consisted of 18 plants in one 9.5-m row, and each whole plot consisted of two subplots plus guard rows

\section{Land preparation}

Timing of field operations is summarized in Table 1. Cereal rye (variety not stated) was seeded with a drill across all fields in October before each field season. In 2012, cereal rye was drilled at $56 \mathrm{~kg} \cdot \mathrm{ha}^{-1}$. Due to an insufficient stand of rye in Spring 2013, the Oct. 2013 seeding rate was increased to $123 \mathrm{~kg} \cdot \mathrm{ha}^{-1}$.

Cereal rye in PL treatments was mowed and tilled in May. Plots were again tilled in

Table 1. Field operations for the 2013 and 2014 summer squash trials in Fruitland, IA.

\begin{tabular}{lcr}
\hline Operation & 2013 & 2014 \\
\hline Cereal rye drilled & 12 Oct. 2012 & 2 Oct. 2013 \\
Rye strip tilled (in ST & 8 Apr. \\
Squash seeded in 72-cell trays & May & 14 May \\
Rye mowed and tilled (in PL ${ }^{y}$ & 9 May & 29 May \\
Rye crimped at anthesis (ST) & 22 May & 29 May \\
Rye strip tilled (in ST) & 3 June & 29 May \\
Soil tilled and plastic laid (in PL) & 3 June & 5 June \\
Squash transplanted, rowcovers laid & 4 June & 5 June \\
Rowcovers removed & 26 June & 1 July \\
\hline
\end{tabular}

${ }^{\mathrm{z}} \mathrm{ST}=$ strip tillage into rolled cereal rye.

${ }^{\mathrm{y}} \mathrm{PL}=$ conventional tillage with black also referred to as plasticulture.

June before laying black plastic mulch $(0.02 \mathrm{~mm}$ thick) using a raised bed plastic mulch layer (Holland Transplanter Model 1275; Holland Transplanter Co., Holland, MI) that creates a $0.7-\mathrm{m}$-wide raised bed with drip tape $(0.3$ emitter spacing, 0.028 $\mathrm{L} \cdot \mathrm{s}^{-1} \cdot 30.5 \mathrm{~m}^{-1}$ ) underneath the plastic.

Cereal rye in ST treatments was mechanically killed using a rear-mounted, chevronpatterned roller crimper (I\&J Manufacturing, Gap, PA). Rolling was performed when cereal rye was at anthesis stage to maximize kill and minimize regrowth (Mirsky et al., 2009). In 2013, strips were made with a strip tiller (6000 Strip-Till; Hiniker Co., Mankato, $\mathrm{MN}$ ) after rolling the rye. There were challenges in strip tilling within the mature rye residue in 2013; the long stalks of cereal rye tended to bind up on the implement coulters, hindering its operation to form a fine seedbed for transplanting squash transplants. The problem was overcome by repeated pulling of cereal rye stalks from the coulters. To mitigate this issue in 2014, an extra pass with the strip tiller was made in early April before rye stem elongation. This approach allowed the strip tiller to work efficiently in the rolled rye residue and form strips in May that were $20 \mathrm{~cm}$ wide. Drip tape was laid on the surface of the strip-tilled zone.

Fertilizer was applied in a 0.6-m-wide band centered on each row after tillage and then incorporated. Fertilizer application was based on a preplant soil test. In 2013, a total of 72 $\mathrm{kg} \cdot \mathrm{ha}^{-1}$ of $\mathrm{N}$ was added by using urea $(46 \mathrm{~N}-\mathrm{OP}-$ $0 \mathrm{~K})$ in the conventionally managed field and an organic fertilizer $(5 \mathrm{~N}-0.4 \mathrm{P}-0.8 \mathrm{~K}$; The Fertrell Company, Bainbridge, PA) in the organically managed field. Conventional tillage with black plastic mulch treatments (PL) received all fertilizer preplant, but ST treatments received one-half preplant and the other half was sidedressed when rowcovers were removed.

In 2014, a system was designed for the conventionally managed field to fertigate $\mathrm{N}$ through drip irrigation. Based on the preplant soil test, a total of $93 \mathrm{~kg} \cdot \mathrm{ha}^{-1}$ of $\mathrm{K}$ and $112 \mathrm{~kg} \cdot \mathrm{ha}^{-1}$ of $\mathrm{N}$ was applied to the conventionally managed field by using $\mathrm{KCl}(0 \mathrm{~N}-0 \mathrm{P}-49.8 \mathrm{~K})$, granular urea, and liquid urea ammonium nitrate $(32 \mathrm{~N}-0 \mathrm{P}-0 \mathrm{~K})$. An organic fertilizer (4N-0.9P-3.3K) (The Fertrell Company) was used in the organically managed field to cover both $\mathrm{N}$ and $\mathrm{K}$ requirements. All treatments in the conventionally managed field received one-third of the total $\mathrm{N}$ requirement preplant with urea, and two-thirds through fertigation with urea ammonium nitrate. Treatments in the organically managed field received all fertilizer preplant because there was not an acceptable organic liquid fertilizer for the fertigation system, and unlike their synthetic counterparts, organic fertilizers take more time to breakdown and release nutrients for plant uptake.

Four-week-old summer squash seedlings were transplanted in June using a mechanical transplanter (Mulch Planter 1265; Holland Transplanter Co.) with an in-row spacing of $56 \mathrm{~cm}$. The same day as transplanting, wire hoops were installed every $1.2 \mathrm{~m}$ down the row in rowcover treatments, and spunbonded rowcovers (AG-30; Agribon, Polymer Group Inc., Charlotte, NC) were placed over the one-row subplot. Rowcover edges in the PL treatments were covered with soil. Edges in ST treatments were held in place using water-filled lay-flat hose to minimize disturbance to the rye mulch and prevent tearing of the rowcover fabric. Rowcovers were removed when $50 \%$ of squash plants had female flowers.

In the conventionally managed field, treatments without rowcovers received an imidacloprid drench (Admire; Bayer CropScience, Research Triangle Park, NC) at planting. In the organically managed field, treatments without rowcovers initially received a foliar spray of spinosad (Entrust SC; Dow AgroSciences, Indianapolis, IN) combined with an insect-feeding stimulant (Cidetrak D; Trécé Inc., Adair, OK). Contrastingly, plants under rowcovers in both systems did not receive any insecticide until rowcovers were removed. After rowcover removal, treatments within each management system were treated the same for insect control.

Fields were scouted weekly for insects and diseases. Pesticide sprays were applied with a backpack sprayer when thresholds were reached. A pheromone trap (Great Lake IPM, Vestaburg, MI) was installed $300 \mathrm{~m}$ from the study site to monitor squash vine borer. When squash vine borer adult moths were found in the trap, a foliar spray of spinosad (Entrust SC; Dow AgroSciences) in the organically managed field or permethrin (Pounce 25WP; FMC Corporation, Philadelphia, PA) in the conventionally managed field was applied to the base of the plants without rowcovers. Thresholds for squash bugs and striped cucumber beetles (A. vittatum) were one egg mass per plant and one insect per plant, respectively. These were controlled in the organically managed fields using spinosad 
(Entrust SC; Dow AgroSciences) and pyrethrin (PyGanic EC50; McLaughlin Gormley King Co., Minneapolis, MN), and were controlled in the conventionally managed fields using permethrins (Pounce; FMC Corporation and Asana; DuPont, Wilmington, DE). Powdery mildew was treated with sulfur (Microthiol Disperss; United Phosphorus, King of Prussia, PA) and neem oil (Trilogy; Certis USA, Columbia, MD) in the organically managed fields, whereas myclobutanil (Rally 40WSP; Dow AngroSciences) was applied in the conventionally managed fields. Plots were hand weeded after rowcover removal in 2013, and no weeding was needed in 2014. In 2013, the entire conventionally managed field was sprayed with a grass herbicide (Poast; BASF Corporation, Research Triangle Park, NC) on 9 July.

\section{Data collection}

Environmental monitoring. Hobo pendant temperature/light sensors (Onset Computer Corporation, Bourne, MA) were attached to wooden stakes placed in direct sun within the row, $15 \mathrm{~cm}$ above the soil surface, in all treatments in three of the four replications in the conventionally managed field, with one sensor for each experimental unit. They recorded air temperature and light intensity every $30 \mathrm{~min}$ throughout the growing season. Hobo pendant temperature sensors were buried within the row, $15 \mathrm{~cm}$ below the soil surface, in all treatments in three of the four replications in the conventionally managed field, with one sensor for each experimental unit. They recorded soil temperature every 60 min throughout the growing season. Environmental monitoring occurred solely in the conventional fields because the differences in management systems (conventional and organic) in our experiment would likely not affect air or soil temperature.

Plant measurements. A SPAD meter (SPAD 502 Plus; Konica Minolta Sensing Americas, Ramsey, NJ) was used to measure leaf chlorophyll content on 15 July 2013 and 12 Aug. 2014 at midday on a sunny day. Measurements were taken on eight plants in each subplot. Two readings from the youngest fully expanded leaf were averaged. Fruit were harvested twice per week, with 14 harvest in 2013 from 2 July to 16 Aug. and 12 harvests in 2014 from 7 July to 15 Aug. Fruit were classified as marketable if they were $15-23 \mathrm{~cm}$ long, had minimal scarring, were well formed, and had no insect damage. The number and total weight of marketable and nonmarketable (cull) squash were recorded for each plot. Because the harvest schedule was insufficient to prevent overgrown squash, marketable yield is reported as number of squash instead of weight, and includes oversized squash that were otherwise marketable. At first harvest, on 2 July 2013 and 7 July 2014, three plants from each plot were excavated for measurement of plant biomass. All fruit were removed from the plants and soil was removed from roots. Plants were placed in paper bags and oven dried at $67^{\circ} \mathrm{C}$ for $5 \mathrm{~d}$ before weighing.

Insects and disease. After the last harvest, plots were assessed for the presence of bacterial wilt, yellow vine decline, and squash vine borer.
Plants that were stunted, wilted, or chlorotic were internally examined for the presence of larva and vascular discoloration. Bacterial wilt and yellow vine decline diagnoses were based on the presence of bacterial ooze and visual symptoms. Subsamples of diseased plants were also cultured on nutrient agar and Luria medium for confirmation.

Soil MBC. Soil samples were taken at the end of each growing season (29 Aug. 2013 and 19 Aug. 2014). Three soil cores (3.8-cm diameter, $15-\mathrm{cm}$ depth) were taken within the row in each plot to make one composite sample per plot. Soil was kept in a sealed bag in a cooler at $4{ }^{\circ} \mathrm{C}$ until analysis. Soil samples were sieved using a 2-mm sieve. The sieve size was deemed appropriate instead of a more common 8-mm sieve (Karlen et al., 2013; Vance et al., 1987) because the sandy texture of the soil made it easy to sieve without much disturbance to the soil even with a smaller mesh size. MBC was extracted using a chloroform fumigation extraction method with a procedure modified from Vance et al. (1987). In 2013, extracts were analyzed on a Phoenix 8000 ultraviolet-Persulfate Total Organic Carbon (TOC) Analyzer (Teledyne Tekmar, Mason, OH). In 2014, a Torch Combustion TOC/TN Analyzer (Teledyne Tekmar) was used. A conversion factor of 0.33 was used when calculating MBC.

\section{Statistical analysis}

Data were analyzed using PROC GLIMMIX and PROC MIXED of SAS (Version 9.3; SAS Institute, Cary, NC). Years and management systems (organic and conventional) were analyzed separately. Replication was treated as a random factor. Mean separation was performed by "lsmeans" and "pdiff" statements using the Satterthwaite method. Percents of insect and disease incidence were transformed using arcsin square root. Unprotected least significant difference was used, thereby allowing for comparisons among treatments even without significant main effects or interactions. This was important because the main research question was not about the whole-plot or subplot treatments themselves, but about how they interacted.

\section{Results}

Weather. Monthly rainfall during the 2013 and 2014 growing seasons was similar to the 20-year average (Table 2), except for lower than average rainfall in July and Aug. 2013. Average monthly growing degree days (GDDs) were similar to the 20 -year average, with fewer GDDs in July both years.

Air temperature and light intensity. In 2013 , rowcovers did not affect minimum air temperature, but they increased mean air temperature by 3.1 to $4.0^{\circ} \mathrm{C}$ and increased maximum air temperature by 6.2 to $10.3{ }^{\circ} \mathrm{C}$ (Table 3 ). In 2014, rowcovers increased minimum air temperature during the early season period by $1.4^{\circ} \mathrm{C}$. Similarly to 2013 , rowcovers increased mean air temperature in both season periods by 1.6 to $2.6^{\circ} \mathrm{C}$. Rowcovers increased maximum air temperature in the early season by $5.4^{\circ} \mathrm{C}$ but had no effect in the midseason period.

Rowcovers decreased average daily mean light intensity by $33 \%$ to $39 \%$ and decreased maximum light intensity by $34 \%$ to $44 \%$, depending on the year (Table 4). The weight of rowcover used in this experiment is expected to have $70 \%$ light transmission

Table 2. Monthly total precipitation and average growing degree days during the 2013 and 2014 growing seasons and the 20-year average at the Muscatine Island Research and Demonstration Farm in Fruitland, IA. ${ }^{2}$

\begin{tabular}{|c|c|c|c|c|c|c|}
\hline \multirow[b]{2}{*}{ Month } & \multicolumn{3}{|c|}{ Monthly precipitation $(\mathrm{mm})$} & \multicolumn{3}{|c|}{ Monthly avg GDD ${ }^{\mathrm{y}}$} \\
\hline & 2013 & 2014 & $20-\operatorname{yr} \operatorname{avg}^{x}$ & 2013 & 2014 & 20 -yr avg \\
\hline June & 154 & 125 & 136 & 345 & 375 & 362 \\
\hline July & 75 & 116 & 88 & 391 & 356 & 426 \\
\hline August & 0.5 & 107 & 104 & 386 & 398 & 403 \\
\hline
\end{tabular}

${ }^{2}$ Monthly data from Iowa Environmental Mesonet at the Muscatine, IA, location.

${ }^{y}$ Growing degree days with base $10{ }^{\circ} \mathrm{C}$ and maximum $30{ }^{\circ} \mathrm{C}$.

×20-year averages from 1995 to 2014.

Table 3. Average daily minimum, mean, and maximum air temperature in conventionally managed summer squash in 2013 and 2014 before rowcovers were removed, averaged across production system treatments, at the Muscatine Island Research and Demonstration Farm in Fruitland, IA.

\begin{tabular}{|c|c|c|c|c|c|c|c|}
\hline \multirow[b]{2}{*}{ Treatment } & \multicolumn{3}{|c|}{ Early season ${ }^{z}$} & \multirow[b]{2}{*}{${ }^{\circ} \mathrm{C}$} & \multicolumn{3}{|c|}{ Midseason $^{y}$} \\
\hline & Min & Mean & Max & & Min & Mean & Max \\
\hline & & & & 2013 & & & \\
\hline Rowcover & 16.3 & 28.9 & 49.8 & & 18.6 & 32.6 & 52.8 \\
\hline No rowcover & 15.7 & 24.9 & 39.5 & & 18.0 & 29.5 & 46.6 \\
\hline$P$ value $^{\mathrm{x}}$ & 0.208 & $<0.0001$ & $<0.0001$ & & 0.210 & $<0.0001$ & $<0.0001$ \\
\hline & & & & $2014^{w}$ & & & \\
\hline Rowcover & 14.9 & 27.0 & 46.4 & & 19.8 & 29.6 & 46.5 \\
\hline No rowcover & 13.5 & 24.4 & 41.0 & & 18.8 & 28.0 & 44.0 \\
\hline$P$ value & 0.007 & $<0.0001$ & $<0.0001$ & & 0.129 & 0.022 & 0.149 \\
\hline
\end{tabular}

${ }^{2}$ Early season: 5-15 June 2013, 6-16 June 2014.

yidseason: 16-25 June 2013, 25-30 June 2014.

${ }^{x} P$ values based on $\mathrm{F}$ test.

${ }^{w}$ A strong storm on 17 June 2014 disrupted a number of sensors. Those sensors were repositioned 24 June 2014. Data from 17 to 24 June 2014 have been discarded. 
when new, but the rowcovers used in this experiment had been used in previous seasons as is the typical practice for most growers using rowcovers.

Soil temperature. In 2013, rowcover had no effect on soil temperature in the ST or PL production systems (Table 5). While minimum soil temperature was unaffected by production system in 2013, PL treatments had higher mean and maximum soil temperature both before and after rowcover removal. Before rowcover removal, mean and maximum soil temperatures were 2.1 and $3.5^{\circ} \mathrm{C}$ higher in PL, respectively. After rowcover removal, mean and maximum soil temperatures were 1.0 and $2.1^{\circ} \mathrm{C}$ higher in PL, respectively.

In contrast, in 2014, rowcovers increased minimum and mean soil temperature by 1.3 and $1.1{ }^{\circ} \mathrm{C}$, respectively, before they were

Table 4. Average daily mean and maximum light intensity in conventionally managed summer squash in 2013 and 2014 before rowcovers were removed, averaged across production system treatments, at the Muscatine Island Research and Demonstration Farm in Fruitland, IA. ${ }^{\mathrm{z}}$

\begin{tabular}{|c|c|c|}
\hline \multirow[b]{2}{*}{ Treatment } & \multicolumn{2}{|c|}{ Light intensity (lumens $/ \mathrm{m}^{2}$ ) } \\
\hline & Mean & Max \\
\hline & \multicolumn{2}{|c|}{2013} \\
\hline Rowcover & 274 & 1,154 \\
\hline No rowcover & 407 & 1,742 \\
\hline \multirow[t]{2}{*}{$P$ value ${ }^{\mathrm{y}}$} & $<0.0001$ & $<0.0001$ \\
\hline & \multicolumn{2}{|c|}{$2014^{x}$} \\
\hline Rowcover & 238 & 1,045 \\
\hline No rowcover & 392 & 1,874 \\
\hline$P$ value & $<0.0001$ & 0.0002 \\
\hline
\end{tabular}

${ }^{\mathrm{z}}$ Rowcover were in place 5-25 June 2013 and 6-30 June 2014.

${ }^{\mathrm{y}} P$ values based on $\mathrm{F}$ test.

${ }^{\mathrm{x}}$ A strong storm on 17 June 2014 disrupted a number of sensors. Those sensors were repositioned 24 June 2014. Data from 17 to 24 June 2014 have been discarded.

Table 5. Average daily minimum, mean and maximum soil temperature at $15-\mathrm{cm}$ depth in conventionally managed summer squash before and after rowcover (RC) removal ${ }^{\mathrm{z}}$ in 2013 and 2014 at the Muscatine Island Research and Demonstration Farm in Fruitland, IA.

\begin{tabular}{|c|c|c|c|c|c|c|c|}
\hline \multirow[b]{2}{*}{ Production system } & \multirow[b]{2}{*}{ Rowcover ${ }^{x}$} & \multicolumn{3}{|c|}{ Before $\mathrm{RC}$ removal ${ }^{\mathrm{z}}\left({ }^{\circ} \mathrm{C}\right)$} & \multicolumn{3}{|c|}{ After $\mathrm{RC}$ removal ${ }^{\mathrm{y}}\left({ }^{\circ} \mathrm{C}\right)$} \\
\hline & & $\operatorname{Min}^{\mathrm{w}}$ & Mean & Max & Min & Mean & Max \\
\hline & & \multicolumn{6}{|c|}{2013} \\
\hline \multirow[t]{2}{*}{ Plasticulture } & $\mathrm{RC}$ & 23.4 & $26.9 \mathrm{a}^{\mathrm{w}}$ & $30.6 \mathrm{a}$ & 22.8 & $26.4 \mathrm{a}$ & $29.7 \mathrm{a}$ \\
\hline & $\mathrm{NRC}$ & 21.6 & $26.3 \mathrm{a}$ & $31.0 \mathrm{a}$ & 20.9 & $25.8 \mathrm{ab}$ & $29.5 \mathrm{a}$ \\
\hline \multirow[t]{3}{*}{ Strip tillage } & $\mathrm{RC}$ & 22.8 & $24.8 \mathrm{~b}$ & $27.2 \mathrm{~b}$ & 23.3 & $25.3 \mathrm{~b}$ & $27.4 \mathrm{~b}$ \\
\hline & $\mathrm{NRC}$ & 21.6 & $24.3 \mathrm{~b}$ & $27.4 \mathrm{~b}$ & 22.1 & $25.0 \mathrm{~b}$ & $27.6 \mathrm{~b}$ \\
\hline & & \multicolumn{6}{|c|}{ Significance } \\
\hline System $(\mathrm{S})^{\mathrm{v}}$ & & 0.661 & $<0.0001$ & 0.003 & 0.420 & 0.018 & 0.002 \\
\hline Rowcover (R) & & 0.066 & 0.096 & 0.457 & 0.152 & 0.217 & 0.966 \\
\hline \multirow[t]{2}{*}{$\mathrm{S} \times \mathrm{R}$} & & 0.736 & 0.967 & 0.802 & 0.733 & 0.702 & 0.705 \\
\hline & & \multicolumn{6}{|c|}{2014} \\
\hline \multirow[t]{2}{*}{ Plasticulture } & $\mathrm{RC}$ & $24.7 \mathrm{a}$ & $27.7 \mathrm{a}$ & $30.9 \mathrm{a}$ & $23.2 \mathrm{a}$ & $25.3 \mathrm{a}$ & $27.8 \mathrm{a}$ \\
\hline & $\mathrm{NRC}$ & $23.5 \mathrm{~b}$ & $26.4 \mathrm{~b}$ & $29.6 \mathrm{ab}$ & $23.1 \mathrm{a}$ & $25.5 \mathrm{a}$ & $28.0 \mathrm{a}$ \\
\hline \multirow[t]{3}{*}{ Strip tillage } & $\mathrm{RC}$ & $22.9 \mathrm{~b}$ & $25.5 \mathrm{bc}$ & $28.2 \mathrm{~b}$ & $21.6 \mathrm{~b}$ & $23.8 \mathrm{~b}$ & $25.9 \mathrm{~b}$ \\
\hline & $\mathrm{NRC}$ & $21.6 \mathrm{c}$ & $24.6 \mathrm{c}$ & $28.3 \mathrm{~b}$ & $21.2 \mathrm{~b}$ & $23.6 \mathrm{~b}$ & $25.9 \mathrm{~b}$ \\
\hline & & \multicolumn{6}{|c|}{ Significance } \\
\hline System & & $<0.0001$ & 0.0001 & 0.003 & 0.002 & 0.001 & 0.003 \\
\hline Rowcover & & $<0.0001$ & 0.006 & 0.273 & 0.541 & 0.954 & 0.870 \\
\hline $\mathrm{S} \times \mathrm{R}$ & & 0.848 & 0.471 & 0.167 & 0.746 & 0.641 & 0.810 \\
\hline
\end{tabular}

${ }^{\mathrm{z} B e f o r e ~ r o w c o v e r ~ r e m o v a l: ~ 5-25 ~ J u n e ~ 2013, ~ 6-30 ~ J u n e ~} 2014$.

y After rowcover removal: 26 June-31 July 2013, 1 July-1 Aug. 2014.

${ }^{\mathrm{x}} \mathrm{RC}=$ rowcover, $\mathrm{NRC}=$ no rowcover.

${ }^{w}$ Mean separation (by year in columns) based on least significant differences at $P \leq 0.05$.

${ }^{\mathrm{v}} P$ values based on $\mathrm{F}$ test.

removed. In 2014, when averaging across rowcover treatments, PL treatments always had higher minimum, mean, and maximum soil temperatures than ST treatments; the daily by 1.7 to $1.8{ }^{\circ} \mathrm{C}$, daily mean soil temperature 1.7 to $2.0{ }^{\circ} \mathrm{C}$, and daily maximum soi temperature by $2.0^{\circ} \mathrm{C}$. However, before the rowcovers were removed, there was no difference in soil temperature between ST with wcover and PL without rowcover.

int biomass and leaf chlorophyll content ors than ST treatments in organically and in the conventionally managed field in 2014, biomass in ST with or without rowcovers did 年 production system or rowcovers on SPAD meter readings; in the conventionally managed field in 2013, however, the plants in ST without rowcovers had the highest SPAD eter readings.

Yield. In the organically managed field, production system affected marketable yield in both years (Table 7). Marketable yield of plants in ST was reduced by $37 \%$ and $30 \%$ compared with yield of plants in PL in 2013 and 2014, respectively. Rowcovers also affected marketable yield in both years in the organically managed field; treatments without rowcovers produced $11 \%$ and $19 \%$ fewer marketable squash compared with treatments with rowcovers in 2013 and 2014, respectively. In 2014, the marketable yield from plants in ST with rowcovers did not differ rom plants in PL without rowcovers. Interaction between production system and rowcover as not statistically significant.

In the conventionally managed field, production system influenced marketable yield in both years (Table 7), as it did in the 
Table 6. Plant biomass and chlorophyl readings in conventionally and organically managed summer squash in 2013 and 2014 at the Muscatine Island Research and Demonstration Farm in Fruitland, IA.

\begin{tabular}{|c|c|c|c|c|c|}
\hline Production system & Rowcover $^{z}$ & Biomass (g/plant) & SPAD & Biomass (g/plant) & SPAD \\
\hline \multicolumn{2}{|c|}{ Organic } & \multicolumn{2}{|l|}{2013} & \multicolumn{2}{|l|}{2014} \\
\hline \multirow[t]{2}{*}{ Plasticulture } & $\mathrm{RC}$ & $47.7 \mathrm{a}^{\mathrm{y}}$ & $37.8 \mathrm{a}$ & $40.2 \mathrm{a}$ & $34.6 \mathrm{a}$ \\
\hline & NRC & $43.5 \mathrm{a}$ & $35.5 \mathrm{a}$ & $37.6 \mathrm{a}$ & $33.9 \mathrm{a}$ \\
\hline \multirow[t]{3}{*}{ Strip tillage } & $\mathrm{RC}$ & $21.0 \mathrm{~b}$ & $36.4 \mathrm{a}$ & $26.4 \mathrm{~b}$ & $36.2 \mathrm{a}$ \\
\hline & NRC & $13.7 \mathrm{~b}$ & $35.6 \mathrm{a}$ & $23.0 \mathrm{~b}$ & $35.7 \mathrm{a}$ \\
\hline & & \multicolumn{4}{|c|}{ Significance } \\
\hline \multicolumn{2}{|l|}{ System $(S)^{x}$} & 0.001 & 0.432 & 0.002 & 0.166 \\
\hline \multicolumn{2}{|l|}{ Rowcover (R) } & 0.080 & 0.086 & 0.409 & 0.630 \\
\hline \multicolumn{2}{|l|}{$\mathrm{S} \times \mathrm{R}$} & 0.595 & 0.369 & 0.912 & 0.944 \\
\hline \multicolumn{2}{|c|}{ Conventional } & \multicolumn{2}{|l|}{2013} & \multicolumn{2}{|l|}{2014} \\
\hline \multirow[t]{2}{*}{ Plasticulture } & $\mathrm{RC}$ & $44.9 \mathrm{a}$ & $36.7 \mathrm{~b}$ & $32.1 \mathrm{a}$ & $35.1 \mathrm{a}$ \\
\hline & NRC & $45.6 \mathrm{a}$ & $36.8 \mathrm{~b}$ & $23.3 \mathrm{~b}$ & $39.5 \mathrm{a}$ \\
\hline \multirow[t]{3}{*}{ Strip tillage } & $\mathrm{RC}$ & $25.5 \mathrm{~b}$ & $39.2 \mathrm{~b}$ & $17.7 \mathrm{~b}$ & $36.3 \mathrm{a}$ \\
\hline & NRC & $19.7 \mathrm{~b}$ & $41.2 \mathrm{a}$ & $16.6 \mathrm{~b}$ & $35.8 \mathrm{a}$ \\
\hline & & \multicolumn{4}{|c|}{ Significance } \\
\hline System & & 0.0001 & 0.038 & 0.0004 & 0.614 \\
\hline Rowcover & & 0.323 & 0.121 & 0.081 & 0.426 \\
\hline $\mathrm{S} \times \mathrm{R}$ & & 0.208 & 0.164 & 0.168 & 0.326 \\
\hline
\end{tabular}

${ }^{\mathrm{z}} \mathrm{RC}=$ rowcover, $\mathrm{NRC}=$ no rowcover.

${ }^{\mathrm{y}}$ Mean separation in columns based on least significant difference at $P \leq 0.05$.

${ }^{\mathrm{x}} P$ values based on $\mathrm{F}$ test.

Table 7. Marketable and nonmarketable (cull) yield of organically and conventionally managed summer squash in 2013 and 2014 at the Muscatine Island Research and Demonstration Farm in Fruitland, IA

\begin{tabular}{|c|c|c|c|c|c|}
\hline \multirow[b]{2}{*}{ Production System } & \multirow[b]{2}{*}{ Rowcover ${ }^{2}$} & Marketable & Cull & Marketable & Cull \\
\hline & & \multicolumn{2}{|c|}{ Yield (no. $\cdot$ ha $\left.^{-1} \times 1000\right)$} & \multicolumn{2}{|c|}{ Yield $\left(\right.$ no. $\cdot$ ha $\left.^{-1} \times 1000\right)$} \\
\hline \multicolumn{2}{|c|}{ Organic } & \multicolumn{2}{|c|}{2013} & \multicolumn{2}{|c|}{2014} \\
\hline \multirow[t]{2}{*}{ Plasticulture } & $\mathrm{RC}$ & $70.8 \mathrm{a}^{\mathrm{y}}$ & $13.9 \mathrm{a}$ & $75.0 \mathrm{a}$ & $8.5 \mathrm{a}$ \\
\hline & NRC & $67.4 \mathrm{a}$ & $13.2 \mathrm{a}$ & $65.6 \mathrm{~b}$ & $9.4 \mathrm{a}$ \\
\hline \multirow[t]{3}{*}{ Strip tillage } & $\mathrm{RC}$ & $48.3 \mathrm{~b}$ & $7.7 \mathrm{~b}$ & $57.2 \mathrm{~b}$ & $7.7 \mathrm{a}$ \\
\hline & NRC & $38.8 \mathrm{c}$ & $4.8 \mathrm{~b}$ & $41.4 \mathrm{c}$ & $8.6 \mathrm{a}$ \\
\hline & & \multicolumn{4}{|c|}{ Significance } \\
\hline \multicolumn{2}{|l|}{ System $(S)^{x}$} & 0.006 & 0.020 & $<0.0001$ & 0.500 \\
\hline \multicolumn{2}{|l|}{ Rowcover (R) } & 0.038 & 0.126 & 0.001 & 0.429 \\
\hline \multicolumn{2}{|l|}{$\mathrm{S} \times \mathrm{R}$} & 0.257 & 0.312 & 0.285 & 0.992 \\
\hline \multicolumn{2}{|c|}{ Conventional } & \multicolumn{2}{|c|}{2013} & \multicolumn{2}{|c|}{2014} \\
\hline \multirow[t]{2}{*}{ Plasticulture } & $\mathrm{RC}$ & $69.1 \mathrm{ab}$ & $14.4 \mathrm{ab}$ & $90.3 \mathrm{a}$ & $10.3 \mathrm{a}$ \\
\hline & NRC & $80.9 \mathrm{a}$ & $15.8 \mathrm{a}$ & $82.9 \mathrm{ab}$ & $9.3 \mathrm{a}$ \\
\hline \multirow[t]{3}{*}{ Strip tillage } & $\mathrm{RC}$ & $59.7 \mathrm{~b}$ & $9.3 \mathrm{~b}$ & $72.6 \mathrm{~b}$ & $9.2 \mathrm{a}$ \\
\hline & $\mathrm{NRC}$ & $58.7 \mathrm{~b}$ & $8.6 \mathrm{~b}$ & $70.8 \mathrm{~b}$ & $7.6 \mathrm{a}$ \\
\hline & & \multicolumn{4}{|c|}{ Significance } \\
\hline System & & 0.016 & 0.011 & 0.007 & 0.373 \\
\hline Rowcover & & 0.178 & 0.843 & 0.334 & 0.296 \\
\hline $\mathrm{S} \times \mathrm{R}$ & & 0.123 & 0.589 & 0.545 & 0.797 \\
\hline
\end{tabular}

${ }^{\mathrm{z}} \mathrm{RC}=$ rowcover, $\mathrm{NRC}=$ no rowcover.

${ }^{\mathrm{y}}$ Mean separation in columns based on least significant difference at $P \leq 0.05$.

${ }^{x} P$ values based on $\mathrm{F}$ test.

Table 8. Percent of plants per row with squash vine borer damage or yellow vine decline symptoms at the end of the season, averaged over production system, in organically and conventionally managed summer squash in 2013 and 2014 at the Muscatine Island Research and Demonstration Farm in Fruitland, IA.

\begin{tabular}{|c|c|c|c|c|}
\hline Rowcover & Yellow vine decline & Squash vine borer & Yellow vine decline & Squash vine borer \\
\hline Organic & \multicolumn{2}{|c|}{2013} & \multicolumn{2}{|c|}{2014} \\
\hline Rowcover & $15.8 \%{ }^{z}$ & $0.0 \%$ & $0.0 \%$ & $1.1 \%$ \\
\hline No rowcover & $14.9 \%$ & $11.9 \%$ & $0.4 \%$ & $4.4 \%$ \\
\hline$P$ value ${ }^{\mathrm{y}}$ & 0.84 & $<0.0001$ & 0.18 & 0.06 \\
\hline Conventional & \multicolumn{2}{|c|}{2013} & \multicolumn{2}{|c|}{2014} \\
\hline Rowcover & $8.9 \%$ & $0.0 \%$ & $0.0 \%$ & $0.4 \%$ \\
\hline No rowcover & $2.1 \%$ & $3.5 \%$ & $0.2 \%$ & $2.1 \%$ \\
\hline$P$ value & 0.06 & 0.01 & 0.34 & 0.29 \\
\hline
\end{tabular}

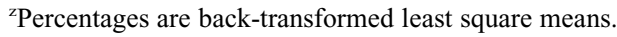

${ }^{\text {y }} P$ values based on $\mathrm{F}$ test.

mulch. Rowcovers increased squash yield in the ST treatments in the organically managed fields only, though we saw equivalent yields of plants in some ST and PL treatments in the conventionally managed fields as well.
We expected rowcovers to have a stronger positive effect on plant biomass production than observed, as rowcovers have been shown to increase plant biomass (Ibarra et al., 2001) and vine cover (Cline et al., 2008) in muskmelon.
Nair and Ngouajio (2010) found that rowcovers increased growth of cucumber when used in a system that incorporated compost. However, because melon and cucumber have a higher optimum growing temperature compared with summer squash, it is expected that summer squash response to rowcovers would be less dramatic than that of melon and cucumber. It is also possible that the rowcovers provided too much additional heat; previous researchers have found that increasing air temperature above $40{ }^{\circ} \mathrm{C}$ can decrease plant biomass (Jenni et al., 1996) and yield (Motsenbocker and Bonanno, 1989) of muskmelon. In this study, even in treatments without rowcovers, air temperatures approached or surpassed an average daily maximum of $40{ }^{\circ} \mathrm{C}$ (Table 3 ), and rowcovers had a neutral or positive effect on plant biomass (Table 6) and marketable yield (Table 7). Because of their placement in the direct sun, however, air temperature sensors likely overestimated temperatures in the treatments without rowcovers. Nonetheless, our results reiterate the strong effect of PL on increased squash vegetative growth (Mahadeen, 2014).

Rowcovers had a more pronounced positive effect on squash yield in the organically managed field compared with the conventionally managed field. This could have been due to a difference in the efficacy of the pesticides used. The organic pesticides may not have been as effective as the conventional pesticides, leading to a larger discrepancy in insect damage and disease spread between rowcover and no-rowcover treatments in the organically managed fields compared with the conventionally managed fields. For example, anthracnose control was not as effective with copper as with conventional fungicides. Indeed, the incidence of squash vine borer damage and yellow vine decline tended to be higher in the organically managed plots without rowcovers than in the conventionally managed plots without rowcovers. This exemplified the advantage of rowcovers in organic management.

Though light intensity was reduced under rowcovers (Table 4), it likely did not impact the growth of plants because rowcovers were in place in June, when there were ample hours of intense sunlight. Even under rowcovers, direct sunlight should have a photon flux density beyond the saturation point for a $\mathrm{C} 3$ plant such as summer squash (Wells and Loy, 1985).

When averaged over rowcover treatments, plants in PL had increased yield and biomass compared with plants in ST in our study. Many researchers have measured the effect of mulch treatments on soil temperature at depths of $10 \mathrm{~cm}$ or less (Bonanno and Lamont, 1987; Ibarra-Jiménez et al., 2004; Schonbeck and Evanylo, 1998; Soltani et al., 1995) and found that black plastic mulch increases soil temperature compared with bare ground by 2 to $4{ }^{\circ} \mathrm{C}$. At a depth of 9 $\mathrm{cm}$, a thick layer of hay reduced afternoon soil temperature compared with bare ground by 2.5 to $4.5{ }^{\circ} \mathrm{C}$ (Schonbeck and Evanylo, 1998). Even at a depth of $15 \mathrm{~cm}$, we found the soil under black plastic mulch was on average 1 to $2{ }^{\circ} \mathrm{C}$ warmer than that in ST (Table 5). In 
Table 9. Soil microbial biomass carbon $\left(\mathrm{mg} \cdot \mathrm{kg}^{-1}\right)$ in conventionally and organically managed summer squash in 2013 and 2014.

\begin{tabular}{|c|c|c|}
\hline Production System & 2013 & 2014 \\
\hline \multicolumn{3}{|l|}{ Organic } \\
\hline Plasticulture & 75.8 & 151.0 \\
\hline Strip tillage & 62.1 & 118.0 \\
\hline$P$ value $^{\mathrm{z}}$ & 0.417 & 0.138 \\
\hline \multicolumn{3}{|l|}{ Conventional } \\
\hline Plasticulture & 85.1 & 125.3 \\
\hline Strip tillage & 69.8 & 114.6 \\
\hline$P$ value & 0.331 & 0.056 \\
\hline
\end{tabular}

${ }^{\mathrm{z} P}$ values based on $\mathrm{F}$ test.

our study, the rye mulch likely did not have much of a cooling effect, as our rye mulch did not cover the soil completely. Growth of rye was potentially limited by the sandy nature of the soil and in conjunction with an October seeding date that did not allow for as much growth in the fall as would occur with an earlier seeding date (Mirsky et al., 2009).

We hypothesized that MBC would be higher in ST treatments than in PL treatments due to the different levels of soil disruption, yet our results were inconsistent (Table 8). We chose to measure MBC specifically because it is known to be more responsive to management practices than other measurements such as soil organic carbon or soil organic matter. We also chose to take the soil samples at the end of the season to avoid the flux of microbial activity that accompanies tillage of residue into the soil; we were more interested in the baseline microbial activity after it stabilized throughout the season. However, some researchers have found no differences in MBC even after multiple consecutive years of tillage treatment differences (Awale et al., 2013; Karlen et al., 2014). Karlen et al. (2013) did find that after at least 26 years, MBC was higher in no-till plots than in those that were tilled with a moldboard plow. In addition, Overstreet and Hoyt (2008) found that after 10 years of strip tilling in the same location each year, the MBC between rows, in the undisturbed region, was higher than that within the annually disturbed region. In our study, the warm soil and organic residue-rich soil in the PL treatments could have provided a beneficial habitat for microbial growth in the short term. We suspect that tillage treatments would need to be established for more than one growing season to see a benefit of a reduced tillage system on the baseline, or end of season, MBC. In addition, another approach called the Community Level Physiological Profiling that focuses on functional aspects related to substrate utilization by soil heterotrophic bacteria could be used to document the impact of production practices on soil microbial diversity.

The air-warming effect of rowcovers often allows growers to plant earlier in the season without risking frost damage. However, in a rolled rye system, early planting is challenging. Cereal rye should be at anthesis when using a roller crimper to kill effectively without regrowth, if not using herbicide (Mirsky et al., 2009), though waiting even longer, until early milk stage, can sometimes provide a more effective kill (Wayman et al., 2014). Maximal biomass production is also needed to suppress weeds effectively and retain moisture (Price and Norsworthy, 2013). Given these requirements, planting of squash is delayed, and rowcovers in a rolled rye system would likely be covering plants during the heat of the summer. This could be a limitation to the ST system.

In this study, weeds were not problematic even in the ST treatments. The squash transplants grew quickly enough to shade out most weeds; in fact, no hand weeding or herbicide application was needed in 2014. It is important to note that in both years, the organically managed field was not certified organic and had been sprayed with herbicide in previous years, in addition to being rotated in and out of agronomic crops, thus likely reducing the weed seed bank in the soil compared with a typical vegetable field. Concerns about weed control in certified organic ST systems remain, but summer squash from transplants look like a promising match for this system due to their rapid growth and quick canopy closure.

Our results show the potential for summer squash in a ST system in both organic and conventional production. Because longterm reduced tillage can increase various aspects of soil health, the option of using a ST system in summer squash production could provide a tool for growers who want to build soil health. Rowcovers could provide a yield boost in a ST system, especially when used in an organically managed system. Overall the rolled rye system has potential to be as productive as plasticulture system but there are issues such as reduced soil GDDs, nutrient immobilization, and weed competition that could arise in the later part of the growing season in such systems (Leavitt et al., 2011).

\section{Literature Cited}

Awale, R., A. Chatterjee, and D. Franzen. 2013. Tillage and $\mathrm{N}$-fertilizer influences on selected organic carbon fractions in a North Dakota silty clay soil. Soil Tillage Res. 134:213-222.

Bonanno, R.A. and W.J. Lamont. 1987. Effect of polyethylene mulches, irrigation method, and row covers on soil and air temperature and yield of muskmelon. J. Amer. Soc. Hort. Sci. 112:735-738.

Bruton, B.D., F. Mitchell, J. Fletcher, S.D. Pair A. Wayadande, U. Melcher, J. Brady, B. Bextine, and T.W. Popham. 2003. Serratia marcescens, a phloem-colonizing, squash bug-transmitted bacterium: Causal agent of cucurbit yellow vine disease. Plant Dis. 87:937-944.

Cirujeda, A., J. Aibar, A. Anzalone, L. Martin-Closas, R. Meco, M.M. Moreno, A. Pardo, A.M. Pelacho, F. Rojo, A. Royo-Esnal, M.L. Suso, and C. Zaragoza. 2012. Biodegradable mulch instead of polyethylene for weed control of processing tomato production. Agron. Sustain. Dev. 32:889-897.

Cline, G.R., J.D. Sedlacek, S.L. Hillman, S.K. Parker, and A.F. Silvernail. 2008. Organic management of cucumber beetles in watermelon and muskmelon production. HortTechnology $18: 436-444$
Delate, K. 2008. Effects of organic fertilization and cover crops on an organic pepper system. HortTechnology 18:215.

Dickey, E.C., C.R. Fenster, J.M. Laflen, and R.H. Mickelson. 1983. Effects of tillage on soil-erosion in a wheat-fallow rotation. Trans. ASAE 26:814 820.

Hemphill, D.D., Jr. 1993. Agricultural plastics as solid waste: What are the options for disposal? HortTechnology 3:70-73.

Hoyt, G.D. 1999. Tillage and cover residue affects on vegetable yields. HortTechnology 9:351-358.

Hoyt, G.D., D.W. Monks, and T.J. Monaco. 1994. Conservation tillage for vegetable production. HortTechnology 4:129-135.

Ibarra-Jiménez, L., M.R. Quezada-Martin, and M. de la Rosa-Ibarra. 2004. The effect of plastic mulch and row covers on the growth and physiology of cucumber. Austral. J. Expt. Agr. 44:91-94

Ibarra, L., J. Flores, and J.C. Diìaz-Pérez. 2001. Growth and yield of muskmelon in response to plastic mulch and row covers. Sci. Hort. 87:139-145.

Jenni, S., D.C. Cloutier, G. Bourgeois, and K.A. Stewart. 1996. A heat unit model to predict growth and development of muskmelon to anthesis of perfect flowers. J. Amer. Soc. Hort. Sci. 121:274-280.

Karlen, D.L., C.A. Cambardella, J.L. Kovar, and T.S. Colvin. 2013. Soil quality response to long-term tillage and crop rotation practices. Soil Tillage Res. 133:54-64.

Karlen, D.L., D.E. Stott, C.A. Cambardella, R.J. Kremer, K.W. King, and G.W. McCarty. 2014. Surface soil quality in five midwestern cropland conservation effects assessment project watersheds. J. Soil Water Conserv. 69:393-401.

Kasirajan, S. and M. Ngouajio. 2012. Polyethylene and biodegradable mulches for agricultural applications: A review. Agron. Sustain. Dev. 32:501-529.

Lamont, W.J., Jr. 2005. Plastics: Modifying the microclimate for the production of vegetable crops. HortTechnology 15:477-481.

Leavitt, M.J., C.C. Sheaffer, D.L. Wyse, and D.L. Allan. 2011. Rolled winter rye and hairy vetch cover crops lower weed density but reduce vegetable yields in no-tillage organic production. HortScience 46:387-395.

Mahadeen, A.Y. 2014. Effect of polyethylene black plastic mulch on growth and yield of two summer vegetable crops under rain-fed conditions under semi-arid region conditions. Amer. J. Agr. Biol. Sci. 9:202-207.

Magdoff, F. and H.M. van Es. 2009. Building soils for better crops. Sustainable Agriculture Research and Education.

Mirsky, S.B., W.S. Curran, D.A. Mortensen, M.R. Ryan, and D.L. Shumway. 2009. Control of cereal rye with a roller/crimper as influenced by cover crop phenology. Agron. J. 101:1589-1596.

Motsenbocker, C.E. and A.R. Bonanno. 1989. Row cover effects on air and soil temperatures and yield of muskmelon. HortScience 24:601-603.

Nair, A. and M. Ngouajio. 2010. Integrating rowcovers and soil amendments for organic cucumber production: Implications on crop growth, yield, and microclimate. HortScience 45:566-574.

Overstreet, L.F. and G.D. Hoyt. 2008. Effects of strip tillage and production inputs on soil biology across a spatial gradient. Soil Sci. Soc. Amer. J. 72:1454-1463.

Parr, M., J.M. Grossman, S.C. Reberg-Horton, C. Brinton, and C. Crozier. 2011. Nitrogen delivery from legume cover crops in no-till organic corn production. Agron. J. 103:1578-1590. 
Peigné, J., B.C. Ball, J. Roger-Estrade, and C. David. 2007. Is conservation tillage suitable for organic farming? A review. Soil Use Mgt. 23:129-144.

Pelosi, C., B. Pey, M. Hedde, G. Caro, Y. Capowiez, M. Guernion, J. Peigné, D. Piron, M. Bertrand, and D. Cluzeau. 2014. Reducing tillage in cultivated fields increases earthworm functional diversity. Appl. Soil Ecol. 83:79-87.

Price, A.J. and J.K. Norsworthy. 2013. Cover crops for weed management in southern reduced-tillage vegetable cropping systems. Weed Technol. 27:212-217.

Reberg-Horton, C., J.M. Grossman, T.S. Kornecki, A.D. Meijer, A.J. Price, G.T. Place, and T.M. Webster. 2012. Utilizing cover crop mulches to reduce tillage in organic systems in the southeastern USA. Renew. Agr. Food Syst. 27:41-48.

Saalau Rojas, E.S., M.L. Gleason, J.C. Batzer, and M. Duffy. 2011. Feasibility of delaying removal of row covers to suppress bacterial wilt of muskmelon (Cucumis melo). Plant Dis. 95:729 734.

Schonbeck, M.W. and G.K. Evanylo. 1998. Effects of mulches on soil properties and tomato production I. Soil temperature, soil moisture and marketable yield. J. Sustain. Agr. 13:55-81.

Snapp, S., S. Swinton, and R. Labarta. 2005. Evaluating cover crops for benefits, costs and performance within cropping system niches Agron. J. 97:322-332.

Soltani, N., J.L. Anderson, and A.R. Hamson. 1995. Growth analysis of watermelon plants grown with mulches and rowcovers. J. Amer. Soc. Hort. Sci. 120:1001-1009.

Teasdale, J.R. 1996. Contribution of cover crops to weed management in sustainable agricultural systems. J. Prod. Agr. 9:475-479.

Vance, E.D., P.C. Brookes, and D.S. Jenkinson 1987. An extraction method for measuring soil microbial biomass-C. Soil Biol. Biochem. 19:703-707.

Walters, S.A. and J.D. Kindhart. 2002. Reduced tillage practices for summer squash production in southern Illinois. HortTechnology 12:114-117.

Wayman, S., C. Cogger, C. Benedict, I. Burke, D. Collins, and A. Bary. 2014. The influence of cover crop variety, termination timing and termination method on mulch, weed cover and soil nitrate in reduced-tillage organic systems. Renewable Agr. Food Systems FirstView:1-11.

Wells, O.S. and J.B. Loy. 1985. Intensive vegetable production with row covers. HortScience 20:822826.

Wyenandt, C.A., R.M. Riedel, L.H. Rhodes, M.A. Bennett, and S.G.P. Nameth. 2011. Fall- and spring-sown cover crop mulches affect yield, fruit cleanliness, and fusarium fruit rot development in pumpkin. HortTechnology 21:343-354. 